\title{
Withdrawal symptoms from phenytoin, carbamazepine and sodium valproate
}

\author{
JOHN S DUNCAN, SIMON D SHORVON, MICHAEL R TRIMBLE \\ From the Institute of Neurology, National Hospital and National Society for Epilepsy Research Group, Institute \\ of Neurology, London and Chalfont Centre for Epilepsy, Chalfont, UK
}

SUMMARY A prospective, double-blind, placebo-controlled investigation of possible withdrawal symptoms from phenytoin, carbamazepine and sodium valproate is reported in patients with active epilepsy, on combination therapy. There was an increase in seizures on reduction and withdrawal of carbamazepine, but there was no convincing evidence of withdrawal symptoms from any of these drugs.

There are well described constellations of symptoms following the withdrawal of ethanol, ${ }^{1-7}$ barbiturates ${ }^{8-13}$ and benzodiazepines, ${ }^{14-26}$ summarised in table 1.

There have been few investigations of possible withdrawal syndromes after cessation of nonbarbiturate antiepileptic drugs (AEDs). Thirty eight patients took 200 to $400 \mathrm{mg}$ phenytoin daily for 1 to 8 months, stopped the drug abruptly and no withdrawal symptoms were noted. ${ }^{27}$ DemersDesrosiers et al $^{29}$ reported two epileptic patients, with no previous history of psychosis, who became psychotic a day after withdrawal of AEDs. Both patients were taking barbiturates as well as phenytoin, and carbamazepine in one, so it is not possible to ascribe the symptoms to withdrawal of either phenytoin or carbamazepine. ${ }^{29}$ Carbamazepine is structurally similar to the tricyclic antidepressants and there are reports of symptoms following withdrawal of these agents (table 1). ${ }^{30-39}$

We report a prospective, placebo-controlled, double-blind study to determine the occurrence of withdrawal symptoms following the reduction and discontinuation of carbamazepine, phenytoin and sodium valproate, in patients with active epilepsy, with each drug being reduced at one of two rates. The effect of these drug changes on seizures is considered in a separate paper (Duncan et al, in preparation).

Address for reprint requests: Dr J S Duncan, National Hospital for Nervous Diseases, Queen Square, London WCIN 3BG, UK.

\section{Methods}

\section{Patients}

Ninety five patients were studied, including a control group of 25 patients who remained on stable therapy. All had active epilepsy, were taking two or more AEDs, and were

Table 1 Clinical features of drug withdrawal

\begin{tabular}{|c|c|c|c|}
\hline Alcohol & Barbiturates & Benzodiazepines & Tricyclics \\
\hline $\begin{array}{l}\text { Anxiety } \\
\text { Agitation } \\
\text { Restlessness } \\
\text { Depression } \\
\text { Weakness } \\
\text { Pruritus } \\
\text { Delirium } \\
\text { Inc. reflexes } \\
\text { Insomnia } \\
\text { Anorexia } \\
\text { Nausea } \\
\text { Vomiting } \\
\text { Sweating } \\
\text { Tremor } \\
\text { Dizziness } \\
\text { Headache } \\
\text { Twitching } \\
\text { Muscle pain } \\
\text { Fever } \\
\text { Impaired } \\
\text { perception: } \\
\text { Visual } \\
\text { Auditory } \\
\text { Tactile } \\
\text { Hallucinations: } \\
\text { Visual } \\
\text { Auditory } \\
\text { Tachycardia } \\
\text { Palpitations } \\
\text { Nystagmus } \\
\text { Seizures }\end{array}$ & $\begin{array}{l}\text { Anxiety } \\
\text { Agitation } \\
\text { Restlessness } \\
\text { Weakness } \\
\text { Disorientation } \\
\text { Delirium } \\
\text { Inc. reflexes } \\
\text { Insomnia } \\
\text { Anorexia } \\
\text { Nausea } \\
\text { Vomiting } \\
\text { Sweating } \\
\text { Tremor } \\
\text { Dizziness } \\
\text { Headache } \\
\text { Twitching } \\
\text { Weight loss } \\
\text { Fever } \\
\text { Impaired } \\
\text { perception: } \\
\text { Visual } \\
\text { Hyperacusis } \\
\text { Olfactory } \\
\text { Gustatory } \\
\text { Hallucinations: } \\
\text { Visual } \\
\text { Auditory } \\
\text { Seizures } \\
\end{array}$ & $\begin{array}{l}\text { Anxiety } \\
\text { Agitation } \\
\text { Restlessness } \\
\text { Depression } \\
\text { Weakness } \\
\text { Impaired memory } \\
\text { Depersonalisation } \\
\text { Derealisation } \\
\text { Insomnia } \\
\text { Anorexia } \\
\text { Nausea } \\
\text { Vomiting } \\
\text { Sweating } \\
\text { Tremor } \\
\text { Dizziness } \\
\text { Headache } \\
\text { Twitching } \\
\text { Muscle pain } \\
\text { Numbness } \\
\text { Paraesthesiae } \\
\text { Photophobia } \\
\text { Impaired } \\
\text { perception: } \\
\text { Hyperacusis } \\
\text { Tactile } \\
\text { Gustatory } \\
\text { Hallucinations: } \\
\text { Visual } \\
\text { Auditory } \\
\text { Paranoia } \\
\text { Incoordination } \\
\text { Flu-like symptoms } \\
\text { Seizures }\end{array}$ & $\begin{array}{l}\text { Anxiety } \\
\text { Agitation } \\
\text { Restlessness } \\
\text { Irritability } \\
\text { Weakness } \\
\text { Mania } \\
\text { Confusion } \\
\text { Insomnia } \\
\text { Anorexia } \\
\text { Nausea } \\
\text { Vomiting } \\
\text { Sweating } \\
\text { Abdominal } \\
\text { cramp } \\
\text { Diarrhoea } \\
\text { Headache } \\
\text { Muscle pain } \\
\text { Chills } \\
\text { Coryza } \\
\text { Vivid dreaming }\end{array}$ \\
\hline
\end{tabular}


Table 4 Numbers of patients developing new symptoms and signs on AED reduction

\begin{tabular}{|c|c|c|c|c|c|c|c|c|}
\hline \multirow[b]{3}{*}{ Symptom } & \multicolumn{8}{|c|}{$A E D$ reduced } \\
\hline & \multicolumn{2}{|c|}{ Phenytoin } & \multicolumn{2}{|c|}{ Carbamazepine } & \multicolumn{2}{|c|}{ Sodium valproate } & \multicolumn{2}{|c|}{ Control } \\
\hline & Fast & Slow & Fast & Slow & Fast & Slow & Fast & Slow \\
\hline Anxiety & 1 & 2 & 1 & 2 & 1 & 1 & 3 & 0 \\
\hline Agitation & 3 & 4 & 0 & 2 & $i$ & 2 & 1 & 2 \\
\hline Irritability & 2 & 3 & 3 & 2 & i & $\overline{1}$ & 0 & 1 \\
\hline Lack of energy & 1 & 2 & 1 & 3 & 2 & 3 & 3 & 5 \\
\hline Imp. memory/concentration & 1 & $\overline{1}$ & 2 & 0 & 1 & 4 & $\hat{1}$ & 0 \\
\hline Depression & 3 & 3 & 3 & 2 & 0 & 1 & 3 & 2 \\
\hline Depersonalisation & 0 & 1 & 2 & 0 & 1 & 0 & 0 & 0 \\
\hline Derealisation & 0 & $i$ & 0 & 0 & 0 & 0 & 0 & 0 \\
\hline Insomnia & 1 & 3 & 4 & 0 & 2 & 1 & 1 & 4 \\
\hline Anorexia & 0 & 2 & 1 & 2 & 2 & 2 & 0 & 2 \\
\hline Headache & 0 & 2 & 2 & 2 & 1 & 1 & 3 & 3 \\
\hline Muscle ache & 1 & 2 & 3 & 2 & 2 & 2 & 2 & 3 \\
\hline Twitching & 3 & 0 & 3 & $\overline{1}$ & 3 & 2 & 0 & 2 \\
\hline Nausea/vomit & 1 & 4 & 0 & 0 & 2 & 0 & 1 & 2 \\
\hline Tremor & 1 & 3 & 2 & 0 & 1 & 1 & 1 & 1 \\
\hline Sweating & 1 & 3 & 0 & 0 & 3 & 3 & 0 & $i$ \\
\hline Dizziness & 1 & 4 & 1 & 0 & 2 & 2 & 1 & 2 \\
\hline Distorted smell/taste & 0 & 0 & 0 & 0 & 0 & 0 & 0 & 0 \\
\hline Paraesthesiae & 0 & 0 & 0 & 0 & 0 & 0 & 0 & 0 \\
\hline Photophobia/sore eyes & 0 & 0 & 0 & 0 & 1 & 0 & 0 & 1 \\
\hline Incoordination & 2 & 0 & 1 & 1 & 1 & 2 & 0 & 1 \\
\hline Hyperacusis & 0 & 0 & 0 & 0 & 0 & 0 & 0 & 0 \\
\hline Flu-like illness & 0 & 0 & 0 & 0 & 0 & 0 & 0 & 1 \\
\hline Hypo/eraesthesiae & 0 & 0 & 0 & 0 & 0 & 0 & 0 & 0 \\
\hline Paranoia & 0 & 1 & 1 & 0 & 0 & 0 & 0 & 0 \\
\hline \multicolumn{9}{|l|}{ Hallucinations } \\
\hline auditory & 0 & 0 & 0 & 0 & 0 & 0 & 0 & 0 \\
\hline visual & 0 & 0 & 0 & 0 & 0 & 0 & 0 & 0 \\
\hline Disorientation & 0 & 0 & 0 & 0 & 0 & 0 & 0 & 0 \\
\hline \multicolumn{9}{|l|}{ Sign } \\
\hline Post hypotension & 1 & 0 & 0 & 2 & 0 & 0 & 0 & 1 \\
\hline Tremor & 0 & 1 & 2 & 0 & 0 & 2 & 0 & 5 \\
\hline Limb ataxia & 0 & 0 & 0 & 0 & 0 & 0 & 0 & 0 \\
\hline Hyper-reflexia & 0 & 0 & 2 & 1 & 0 & 1 & 1 & 1 \\
\hline Inc. blink reflex & 0 & 0 & 0 & 0 & 0 & 0 & 0 & 0 \\
\hline Nystagmus & 1 & 0 & 0 & 0 & 0 & 0 & 0 & 1 \\
\hline Gait ataxia & 1 & 1 & 1 & 0 & 0 & 0 & 0 & 1 \\
\hline \multicolumn{9}{|c|}{ Numbers of patients with increased symptom rating scale scores } \\
\hline Anxiety & 3 & 3 & 0 & 3 & 2 & 4 & 2 & 1 \\
\hline Tension & 2 & 3 & 0 & 2 & 3 & 2 & 2 & 1 \\
\hline Depression & 0 & 3 & 2 & 3 & 4 & 5 & 2 & 1 \\
\hline Shaking & 2 & 3 & 3 & 1 & 4 & 3 & $\overrightarrow{1}$ & $i$ \\
\hline Nausea & 0 & 2 & 0 & 0 & 3 & 4 & 0 & 1 \\
\hline Palpitations & 2 & 1 & 1 & 0 & 1 & 2 & 0 & 0 \\
\hline Faintness & 0 & 0 & 2 & 0 & 3 & 2 & 0 & 0 \\
\hline Total patient numbers & 10 & 12 & 13 & 10 & 14 & 11 & 13 & 12 \\
\hline
\end{tabular}

DF, $p=0.05$ ). This was the result of a higher level of shaking in the baseline than reduction $(Z=-2 \cdot 4, p$ $=0.02$ ) periods, in this group. This reduction of shaking was not a consistent effect of carbamazepine reduction as, if the fast and slow streams were analysed together there were no longer any significant changes with time. Nonparametric tests did not reveal any other significant changes. Two patients became very withdrawn, and one of these also became suspicious, paranoid and uncooperative, after the withdrawal of carbamazepine. In both cases, however, the changes in affect followed a marked increase in seizures and the restoration of carbamazepine, in these two patients, was followed by an immediate reduction in seizure frequency, and return of affect to normal.

\section{Discussion}

There have not been any previous systematic investigations of symptoms following withdrawal of phenytoin, carbamazepine or sodium valproate. The present study was prospective, placebo-controlled and double-blind. Withdrawal symptoms cannot be clearly identified without a blind, controlled study and these aspects have been neglected in some previous investigations.

In this study, there was no convincing evidence for the development of a withdrawal syndrome, following the reduction and cessation of treatment with these drugs. There was no significant change in seizure numbers in the phenytoin, sodium valproate or control 
groups. Seizures increased on carbamazepine reduction and this increase was maintained through the 4 weeks after withdrawal (Duncan et al, in preparation). The two patients who were noted to have a change in affect after withdrawal of carbamazepine both had a marked increase in seizures at this time, so it is not possible to ascribe these changes directly to the withdrawal of the drug, rather than to a post-ictal effect.

Several possible reasons for the absence of an identifiable withdrawal syndrome in this study need consideration. The size of the patient groups was relatively small. The patient groups were well matched for important variables, the minor differences in age are not likely to have influenced the results. AED reduction was gradual, over 1 to 7 weeks, baseline drug levels were not high, and all patients were also taking at least one other AED. Further, there was a low prevalence of psychiatric disturbance (13/95) in the subjects of this investigation, compared with most studies of the withdrawal of sedative drugs, and patients with such problems may be more likely to note symptoms. The assessment of possible withdrawal symptoms was made weekly; it is possible that minor, transient symptoms were not noted by the patients, but it is not likely that any significant reactions were overlooked. The assessment schedule was deliberately simple; it is conceivable that a more sophisticated enquiry may have yielded positive results. The statistical analysis, however, was sensitive and was designed to identify both numbers of patients who had new symptoms and a significant increase in rating scales, and also to detect more subtle underlying changes in scores.

Phenytoin, carbamazepine and sodium valproate are relatively non-sedating and do not have the acute, intense, habit-forming psychotropic effects that are associated with barbiturates, benzodiazepines and alcohol, and this may explain why there were no rebound effects following withdrawal of these AEDs. However, carbamazepine and sodium valproate have been noted to ameliorate the symptoms of the alcohol withdrawal syndrome $e^{4546}$ and carbamazepine has been claimed to minimise the effects of alprazolam withdrawal. ${ }^{47}$ If verified, these findings would indicate that there may be some cross-tolerance between sedative drugs and carbamazepine and sodium valproate.

Carbamazepine has a similar structure to tricyclic antidepressants, and there is a well defined tricyclic withdrawal syndrome. Most features of this syndrome, however, respond to atropine, suggesting that they are the result of cholinergic supersensitivity, and carbamazepine has some anticholinergic activity. ${ }^{48}$ In the current investigation, there was no convincing evidence of a "tricyclic withdrawal syndrome" following removal of carbamazepine.

In conclusion, it does not seem likely that a significant withdrawal syndrome could have developed in these patients and not been noted. A likely explanation of the negative result is that withdrawal of phenytoin, carbamazepine and sodium valproate at these rates, in patients who are remaining on one or more other AEDs, is not associated with any significant withdrawal symptoms, other than seizures. It appears improbable that withdrawal symptoms are likely to be a clinical problem, when these AEDs are discontinued in clinical practice.

We are grateful to Dr A L Johnson for statistical advice, Ms M Fuller for advice on computing and the staff of the Chalfont Centre for Epilepsy for active cooperation. These studies were supported by Ciba-Geigy Pharmaceuticals, the Brain Research Trust, the Raymond Way Memorial Fund and The Thorn Epilepsy Research Fund. Matching placebos were supplied by Ciba-Geigy Pharmaceuticals (carbamazepine), Evans Medical (phenytoin) and LabazSanofi (sodium valproate).

\section{References}

1 Isbell H, Fraser HF, Wikler A, Belleville RE, Eisenman AJ. An experimental study of the aetiology of "rum fits" and delirium tremens. Quarterly Journal of Studies in Alcohol 1955;16:1-33.

2 Klett CJ, Hollister LE, Caffey EM, Kaim SC. Evaluating changes in symptoms during acute alcohol withdrawal. Arch Gen Psychiatry 1971;24:174-8.

3 Gross MM, Lewis E, Hastey J. Acute alcohol withdrawal syndrome. In: Kissin B, Begleiter $\mathrm{H}$, eds. The Biology of Alcoholism Vol 3. Clinical Pathology. New York: Plenum Press, 1974:191-263.

4 Bjorkquist SE, Isohanni M, Makela R, Malinen L. Ambulant treatment of alcohol withdrawal symptoms with carbamazepine - a double blind trial. Acta Psychiatr Scand 1976;53:333-42.

5 Thompson WL. Management of alcohol withdrawal syndromes. Arch Int Med 1978;138:278-83.

6 Drake ME. Recurrent spontaneous myoclonus in alcohol withdrawal. South Med J 1983;76:1040-2.

7 Flygenring J, Hansen J, Holst B, Petersen E, Sorensen A. Treatment of alcohol withdrawal symptoms in hospitalized patients. Acta Psychiatr Scand 1984;69:398-408.

8 Isbell H, Altschul S, Kornetsky CH, Eisenman AJ, Flanary HG, Fraser HF. Chronic barbiturate intoxication. Arch Neurol Psychiatry 1950;64:1-28.

9 Alexander EJ. Withdrawal effects of sodium amytal. Dis Nerv Syst 1951;12:77-82.

10 Fraser HF, Wikler A, Essig CF, Isbell H. Degree of physical dependence induced by secobarbital or pentobarbital. JAMA 1958;166:126-9.

11 Wulff $\mathrm{MH}$. The barbiturate withdrawal syndrome. A clinical and electroencephalographic study. Electroencephalogr Clin Neurophysiol 1959;Suppl 14:1-168.

12 Gardner AJ. Withdrawal fits in barbiturate addicts. Lancet 1967;ii:337-8.

13 Khantzian EJ, McKenna GJ. Acute toxic and withdrawal reactions associated with drug use and abuse. Ann Int Med 1979;90:361-72.

14 Hollister LE, Motzenbecker FP, Degan RO. Withdrawal reac- 
tions from chlordiazepoxide ("Librium"). Psychopharmacologia 1961;2:63-8.

15 Ayd FJ. Benzodiazepines: dependence and withdrawal. JAMA 1979;242:1401-2.

16 Petursson H, Lader MH. Withdrawal from long-term benzodiazepine treatment. Br Med J 1981;283:643-5.

17 Rickels K. Are benzodiazepines overused and abused? Br J Clin Pharmacol 1981;11:71S-83S.

18 Tyrer P, Rutherford D, Huggett T. Benzodiazepine withdrawal symptoms and propranolol. Lancet 1981;i:520-2.

19 Lader M. Benzodiazepine withdrawal states. In: Trimble MR, ed. Benzodiazepines Divided. Chichester: John Wiley, 1983:17-32.

20 Marks J. The benzodiazepines-for good or evil. Neuropsychobiology 1983;10:115-26.

21 Schopf J. Withdrawal phenomena after long term administration of benzodiazepines. A review of recent investigations. Pharmacopsychiatrica 1983;16:1-8.

22 Tyrer P, Owen R, Dawling S. Gradual withdrawal of diazepam after long term therapy. Lancet 1983;i:1402-6.

23 Ashton $\mathrm{H}$. Benzodiazepine withdrawal: an unfinished story. $\mathrm{Br}$ Med J 1984;288:1135-40.

24 Fontaine R, Chouinard G, Annable L. Rebound anxiety in anxious patients after abrupt withdrawal of benzodiazepine treatment. Am J Psychiatry 1984;141:848-52.

25 Petursson H, Lader MH. Benzodiazepine tolerance and withdrawal syndrome. In: Burrows GD, Werry JS, eds. Advances in Human Psychopharmacology. Greenwich, Connecticut: JAI Press, 1984:89-119.

26 Higgitt AC, Lader MH, Fonagy P. Clinical management of benzodiazepine dependence. Br Med J 1985;291:688-90.

27 Rosenblum JA, Shafer NS. Effects of diphenylhydantoin (Dilantin) withdrawal on non-epileptics: preliminary report. Current Therapeutics Research 1970;12:31-3.

28 Rosenblum JA. Diphenylhydantoin Sodium (Dilantin) withdrawal in non-epileptics. Current Therapeutics Research 1971:13:369-73.

29 Demers-Desrosiers LA, Nestoros JN, Vaillancourt P. Acute psychosis precipitated by withdrawal of anticonvulsant medication. Am J Psychiatry 1978;135:981-2.

30 Andersen $\mathrm{H}$, Kristiansen ES. Tofranil treatment of endogenous depression. Acta Psychiatr Neurol Scand 1959;34:387-97.

31 Kramer JC, Klein DF, Fink M. Withdrawal symptoms following discontinuation of imipramine therapy. Am J Psychiatry 1961;118:549-50.

32 Shatan C. Withdrawal symptoms after abrupt termination of imipramine. Canadian Psychiatric Association Journal 1966; Suppl 2:150-8.

33 Gualtieri CT, Staye J. (1979). Withdrawal symptoms after abrupt cessation of amitryptiline in an eight year old boy. Am J Psychiatry 1979;136:457-8.

34 Santos AB, McCurdy L. Delirium after abrupt withdrawal from doxepin: case report. Am J Psychiatry 1980;137:239-40.

35 Stern SL, Mendels J. Withdrawal symptoms during the course of imipramine therapy. J Clinical Psychiatry 1980;41:66-7.

36 Mirin SM, Schatzberg AF, Creasey DE. Hypomania and mania after withdrawal of tricyclic antidepressants. Am J Psychiatry 1981;138:87-9.

37 Dilsaver SC, Greden JF. Antidepressant withdrawal phenomena: a review. Biol Psychiatry 1984;19:237-56.

38 Dilsaver SC, Greden JF. Antidepressant withdrawal-induced activation (hypomania and mania): mechanism and theoretical significance. Brain Research Reviews 1984;7:29-48.

39 Patterson JF. Psychosis after discontinuation of nortryptyline. $J$ Clin Psychopharmacol 1984;4:117-8.

40 Covi L, Lipman RS, Pattison JH, Derogatis LR, Uhlenhuth EH. Length of treatment with anxiolytic sedatives and response to their sudden withdrawal. Acta Psychiatr Scand 1973;49:51-64.

41 Winokur A, Rickels K, Greenblatt DJ, Snyder PJ, Schatz NJ. Withdrawal reactions from long-term low dosage administration of diazepam. Arch Gen Psychiatry 1980;37:101-5.

42 Power KG, Jerrom DWA, Simpson RJ, Mitchell M. Controlled study of withdrawal symptoms and rebound anxiety after six week course of diazepam for generalized anxiety. $\mathrm{Br} \mathrm{Med} J$ 1985;290:1246-8.

43 Armitage P. Statistical Methods in Medical Research. Oxford: Blackwell, 1971:427-33.

44 Siegel S. Nonparametric Statistics for the Behavioural Sciences. New York: McGraw Hill, 1956.

45 Wilbur R, Kulik FA. Anticonvulsant drugs in alcohol withdrawal: use of phenytoin, primidone, carbamazepine, valproic acid and the sedative anticonvulsants. Am J Hospital Pharmacy 1981;38:1138-43.

46 Butler D, Messiha FS. Alcohol withdrawal and carbamazepine Alcohol 1986:3:113-30.

47 Klein E, Uhde TW, Post RM. Preliminary evidence for the utility of carbamazepine in alprazolam withdrawal. Am J Psychiatry 1986;143:235-6.

48 Masland RL. Carbamazepine. Neurotoxicity. In: Woodbury DM, Penry JK, Pippenger CE, eds. Antiepileptic Drugs. New York: Raven Press, 1982:521-31. 